\title{
Grazing effects on nutritional quality of bluebunch wheat- grass for elk
}

\author{
CARL L. WAMBOLT, MICHAEL R. FRISINA, KRISTIN S. DOUGLASS, AND HARRIE W. SHERWOOD
}

\begin{abstract}
Authors are professor, Department of Animal and Range Sciences, Montana State University, Bozeman, Mont. 59717; wildlife biologist and wildlife technician, Montana Fish, Wildlife, \& Parks, 1330 W. Gold Street, Butte, Mont. 59701; and research associate, Department of Animal and Range Sciences, Montana State University, Bozeman, Mont. 59717.
\end{abstract}

\begin{abstract}
We tested the hypothesis that nutrient content of bluebunch wheatgrass (Agropyron spicatum [Pursh] Scribn. \& Smith) either cattle grazed in the spring, rested from cattle grazing for a full year, or given long term rest would all be equal during the given season at 1 location. $A 3$ pasture rest-rotation grazing system and an exclosure on the Mt. Fleecer elk winter range in southwestern Montana were studied during 4 seasons over 3 years. Only nitrogen (N) and phosphorus contents were generally greater in the spring grazed regrowth pasture. However, regrowth from bluebunch wheatgrass grazed in the spring did not improve the species nutrient content for wildlife the following winter over nongrazed treatments. During winter when elk (Cervus elaphus nelsoni Bailey) are present, N, TDN, and IVDMD were not different among the 3 treatments. Elk were determined unlikely to consume enough bluebunch wheatgrass to meet protein maintenance requirements during winter. Our findings resulted from analyses repeated over the 3 years for a complete cycle of a 3 pasture restrotation system: however, our hypothesis needs to be tested at other locations before assuming the same results elsewhere.
\end{abstract}

Key Words: Agropyron spicatum, Cervus elaphus, big game nutrition, grazing system, crude protein

Anderson and Scherzinger (1975) and Anderson et al. (1990) postulated that cattle grazing could improve the quality of winter forage for elk (Cervus elaphus nelsoni Bailey). Their reasoning was largely based on conjecture that cattle grazing in the spring delays senescence. Therefore, nutrients in bunchgrasses are retained into the winter for herbivore use, unlike an ungrazed bunchgrass that translocates its nutrients to the roots before winter. Consequently, this concept was included in the development of many grazing systems (Frisina and Morin 1991).

Several studies (Uresk and Cline 1976, Wilms et al. 1980 , Dragt 1985, Pitt 1986, Westenskow-Wall et al. 1994) considered different aspects of the Anderson and Scherzinger (1975) and Anderson et al. (1990) postulation. However, none considered the

Research was funded by the Deerlodge National Forest and Montana Fish, Wildlife, \& Parks. Authors wish to thank Forest Morin and Jina Mariani, USFS, for their support,

Manuscript accepted 26 Oct. 1996. effects of an existing livestock grazing system on the primary nutrients available to wintering elk. Severson and Umess (1994) conclude that native ungulate performance on winter ranges is often limited by forage quality and that further study is necessary because existing studies have left much unanswered. Our objective was to determine if 3 livestock grazing treatments influence the nutrient content of bluebunch wheatgrass (Agropyron spicatum [Pursh] Scribn. \& Smith) during different seasons. The treatments compared included the spring grazed pasture (regrowth) and the rest pasture ( 1 year of rest) from a rest-rotation system, and long term rest from an exclosure located within the rest-rotation system. Our hypothesis was that the nutrient content of bluebunch wheatgrass grazed by cattle in the spring, or rested from cattle grazing for a full year, both within our typical 3 pasture restrotation system, or given long term rest (exclosure), would all be equal during a given season over a 3 year cycle for the system.

\section{Methods}

\section{Study Area}

The study area is an important elk winter range on the southeast face of Mt. Fleecer in southwestern Montana. The Fleecer elk winter range is located $40 \mathrm{~km}$ southwest of Butte. Frisina and Morin (1991) described a large cooperative effort between Montana Fish, Wildlife, \& Parks, Deerlodge National Forest, and the Smith 6 Bar S Livestock Company that included 12 pastures. Our study utilized the 3 pastures on the Montana Fish, Wildlife, \& Parks land. These pastures range from $1,700 \mathrm{~m}$ to $1,950 \mathrm{~m}$ in elevation. The pastures are dominated by bluebunch wheatgrass. Average annual precipitation is $320 \mathrm{~mm}$ at Divide located on the southeast corner of the pastures. Soils are Ochrepts, Boralfs, and Borolls within these pastures.

The 3 pastures contain a total of 1,680 ha and were gradually put under rest-rotation grazing management (Hormay 1970) for cattle between 1981 and 1987 . The rested pasture provided a full growing season of plant growth for winter elk forage. A second pasture was used only in early spring with the cattle removed during late May. This treatment provided almost as much forage for wintering elk as the rested pasture (Frisina and Morin 1991). The third pasture received only late fall grazing between 1 October and 15 October by $100 \mathrm{AU}$ 's which also left adequate forage for wintering elk. Bluebunch wheatgrass from the pastures grazed in the late fall was not sampled for nutrient content. Frisina and 
Morin (1991) provided additional historical perspectives of the area and its management including specific pasture use.

\section{Sampling and Analysis}

Bluebunch wheatgrass was clipped to a $3 \mathrm{~cm}$ stubble height for nutritional analyses. To maintain as much consistency as possible among the sampling seasons only vegetative material of current year's growth was sampled. Clippings during the summer, fall, and winter in the spring grazed pastures were only taken from plants that had been grazed in the spring by cattle. Samples were collected at 4 seasons during each of 3 years so the 3 pasture restrotation system would complete a rotation cycle during the study. These 4 seasons corresponded to bluebunch wheatgrass growth stages as follows: mid June (full flowering), mid August (seed ripe), late October (cessation of fall regrowth), and late December (dormancy). Ten, $1 \mathrm{~m}^{2}$ plots were randomly located each sampling period within each treatment and used to slip $50 \mathrm{~g}$ (dry weight) samples for nutritional analysis with a portion coming from each grazed plant in the plot. This resulted in 10 samples each season ( 30 over the 3 year study) per treatment. Plant material was air dried prior to nutritional analysis.

Nutritional analysis was conducted by the Oscar $\mathrm{O}$. Thomas Nutrition Center at Montana State University. Grass samples were analyzed for dry matter (DM), nitrogen $(\mathrm{N})$, calcium, ether extract (EE), and ash according to AOAC (1980) procedures. Acid detergent fiber (ADF) and acid detergent insoluble nitrogen (ADIN) were determined using procedures described by Goering and Van Soest (1970) and neutral detergent fiber (NDF) followed the method of Robertson and Van Soest (1977). In vitro dry matter digestibility (IVDMD) determination followed the Barnes modification of the Tilley and Terry in vitro technique (Harris 1970). Bovine rumen fluid inocula from 2 rumen canulated animals was composited for this procedure which was conducted in duplicate. Phosphorus determination followed Fiske and Sabbarow (1925). The calculation of total digestible nutrients (TDN) followed Jurgens (1993).

A one-way ANOVA for each nutrient with grazing treatment as the factor was conducted for each of the 4 seasons over the 3 year study. Because seasonal differences in nutrient content are well established, separating possible grazing treatment differences within each season was our goal. The Least Significant Difference (LSD) method ( $\mathbf{P} \leq 0.05)$ protected by a prior F-test $(\mathbf{P} \leq 0.05)$ was used for comparing treatment means (Snedecor and Cochran 1980). All differences discussed are significant at the 5\% level unless otherwise indicated

\section{Results and Discussion}

Nitrogen and phosphorus contents were generally greater in the spring grazed regrowth pasture (Table 1 ). The only exception was that $\mathrm{N}$ contents during the winter were not different among the 3 treatments. Winter is the season of greatest interest because elk are utilizing the forage. However, during winter the spring grazed bluebunch wheatgrass does not possess more $\mathrm{N}$ than that from the 2 treatments ungrazed the previous suinmer. The low ADIN values for all seasons indicate that nearly all of the $\mathrm{N}$ is available to the animals grazing the bluebunch wheatgrass throughout the year. During all seasons except fall, $\mathrm{N}$ levels were not different between the grazing treatments receiving 1 year of rest or long-
Table 1. Nutrient contents $(\%)$ of bluebunch wheatgrass dry matter by grazing treatment and season averaged over the 3 year study.

\begin{tabular}{|c|c|c|c|c|c|}
\hline Nutrient & $\begin{array}{l}\text { Grazing } \\
\text { Treatment }\end{array}$ & Spring & Summer & Fall & Winter \\
\hline$N$ & $\begin{array}{l}\text { Spring } \\
1 \text { year rest } \\
\text { Exclosure }\end{array}$ & $\begin{array}{l}1.82^{\mathrm{a}} \\
1.60^{\mathrm{h}} \\
1.54^{\mathrm{b}}\end{array}$ & $\begin{array}{l}1.09^{\mathrm{a}} \\
0.94^{\mathrm{b}} \\
0.88^{\mathrm{b}}\end{array}$ & $\begin{array}{l}0.74^{\mathrm{a}} \\
0.61^{\mathrm{h}} \\
0.53^{\mathrm{c}}\end{array}$ & $\begin{array}{l}0.51^{\mathrm{a}} \\
0.46^{\mathrm{a}} \\
0.46^{\mathrm{a}}\end{array}$ \\
\hline TDN & $\begin{array}{l}\text { Spring } \\
1 \text { year rest } \\
\text { Exclosure }\end{array}$ & $\begin{array}{l}69.1^{\mathrm{c}} \\
70.0^{\mathrm{b}} \\
71.2^{\mathrm{a}}\end{array}$ & $\begin{array}{l}66.9^{\mathrm{b}} \\
68.0^{\mathrm{a}} \\
67.5^{\mathrm{ab}}\end{array}$ & $\begin{array}{l}63.7^{\mathrm{a}} \\
64.5^{\mathrm{a}} \\
64.3^{\mathrm{a}}\end{array}$ & $\begin{array}{l}62.3^{\mathrm{a}} \\
63.7^{\mathrm{a}} \\
63.4^{\mathrm{a}}\end{array}$ \\
\hline IVDMD & $\begin{array}{l}\text { Spring } \\
1 \text { year rest } \\
\text { Exclosure }\end{array}$ & $\begin{array}{l}55.2^{\mathrm{a}} \\
52.8^{\mathrm{a}} \\
52.7^{\mathrm{a}}\end{array}$ & $\begin{array}{l}46.2^{\mathrm{a}} \\
40.3^{\mathrm{b}} \\
35.7^{\mathrm{c}}\end{array}$ & $\begin{array}{l}30.0^{\mathrm{a}} \\
24.4^{\mathrm{b}} \\
25.3^{\mathrm{ab}}\end{array}$ & $\begin{array}{l}23.4^{\mathrm{a}} \\
21.5^{\mathrm{a}} \\
21.1^{\mathrm{a}}\end{array}$ \\
\hline $\mathrm{EE}$ & $\begin{array}{l}\text { Spring } \\
1 \text { year rest } \\
\text { Exclosure }\end{array}$ & $\begin{array}{l}2.8^{\mathrm{b}} \\
3.1^{\mathrm{a}} \\
3.0^{\mathrm{ab}}\end{array}$ & $\begin{array}{l}4.2^{\mathrm{a}} \\
3.9^{\mathrm{ab}} \\
3.7^{\mathrm{b}}\end{array}$ & $\begin{array}{l}4.6^{\mathrm{a}} \\
3.7^{\mathrm{b}} \\
3.5^{\mathrm{b}}\end{array}$ & $\begin{array}{l}3.2^{\mathrm{a}} \\
2.9^{\mathrm{ab}} \\
2.6^{\mathrm{b}}\end{array}$ \\
\hline NDF & $\begin{array}{l}\text { Spring } \\
1 \text { year rest } \\
\text { Exclosure }\end{array}$ & $\begin{array}{l}65.9^{\mathrm{a}} \\
66.0^{\mathrm{a}} \\
65.4^{\mathrm{a}}\end{array}$ & $\begin{array}{l}62.6^{\mathrm{b}} \\
67.0^{\mathrm{a}} \\
68.1^{\mathrm{a}}\end{array}$ & $\begin{array}{l}70.8^{\mathrm{b}} \\
71.3^{\mathrm{b}} \\
73.2^{\mathrm{a}}\end{array}$ & $\begin{array}{l}72.6^{\mathrm{b}} \\
74.0^{\mathrm{a}} \\
74.5^{\mathrm{a}}\end{array}$ \\
\hline ADF & $\begin{array}{l}\text { Spring } \\
1 \text { year rest } \\
\text { Exclosure }\end{array}$ & $\begin{array}{l}37.3^{\mathrm{a}} \\
36.6^{\mathrm{ab}} \\
35.8^{\mathrm{b}}\end{array}$ & $\begin{array}{l}40.7^{\mathrm{b}} \\
41.8^{\mathrm{ab}} \\
43.0^{\mathrm{a}}\end{array}$ & $\begin{array}{l}48.0^{\mathrm{ab}} \\
47.1^{\mathrm{b}} \\
48.8^{\mathrm{a}}\end{array}$ & $\begin{array}{l}48.5^{b} \\
48.2^{b} \\
49.9^{a}\end{array}$ \\
\hline Ash & $\begin{array}{l}\text { Spring } \\
1 \text { year rest } \\
\text { Exclosure }\end{array}$ & $\begin{array}{l}8.2^{\mathrm{a}} \\
8.1^{\mathrm{a}} \\
7.0^{\mathrm{b}}\end{array}$ & $\begin{array}{r}11.6^{\mathrm{a}} \\
9.7^{\mathrm{b}} \\
9.5^{\mathrm{b}}\end{array}$ & $\begin{array}{l}12.9^{\mathrm{a}} \\
11.4^{\mathrm{b}} \\
10.6^{\mathrm{b}}\end{array}$ & $\begin{array}{l}12.7^{\mathrm{a}} \\
10.9^{\mathrm{b}} \\
10.2^{\mathrm{b}}\end{array}$ \\
\hline $\mathrm{Ca}$ & $\begin{array}{l}\text { Spring } \\
1 \text { year rest } \\
\text { Exclosure }\end{array}$ & $\begin{array}{l}0.38^{\mathrm{a}} \\
0.37^{\mathrm{a}} \\
0.28^{\mathrm{b}}\end{array}$ & $\begin{array}{l}0.57^{\mathrm{a}} \\
0.47^{\mathrm{b}} \\
0.38^{\mathrm{c}}\end{array}$ & $\begin{array}{l}0.53^{\mathrm{a}} \\
0.54^{\mathrm{a}} \\
0.38^{\mathrm{b}}\end{array}$ & $\begin{array}{l}0.48^{\mathrm{a}} \\
0.49^{\mathrm{a}} \\
0.35^{\mathrm{b}}\end{array}$ \\
\hline$P$ & $\begin{array}{l}\text { Spring } \\
1 \text { year rest } \\
\text { Exclosure }\end{array}$ & $\begin{array}{l}0.23^{\mathrm{a}} \\
0.21^{\mathrm{b}} \\
0.19^{\mathrm{c}}\end{array}$ & $\begin{array}{l}0.13^{\mathrm{a}} \\
0.11^{\mathrm{b}} \\
0.10^{\mathrm{b}}\end{array}$ & $\begin{array}{l}0.11^{\mathrm{a}} \\
0.09^{\mathrm{b}} \\
0.08^{\mathrm{b}}\end{array}$ & $\begin{array}{l}0.09^{\mathrm{a}} \\
0.07^{\mathrm{b}} \\
0.06^{\mathrm{c}}\end{array}$ \\
\hline ADIN & $\begin{array}{l}\text { Spring } \\
1 \text { year rest } \\
\text { Exclosure }\end{array}$ & $\begin{array}{l}2.9^{\mathrm{a}} \\
2.5^{\mathrm{a}} \\
2.5^{\mathrm{a}}\end{array}$ & $\begin{array}{l}3.9^{\mathrm{a}} \\
3.4^{\mathrm{b}} \\
3.8^{\mathrm{a}}\end{array}$ & $\begin{array}{l}3.9^{\mathrm{a}} \\
3.3^{\mathrm{a}} \\
3.9^{\mathrm{a}}\end{array}$ & $\begin{array}{l}3.8^{\mathrm{a}} \\
3.5^{\mathrm{a}} \\
3.8^{\mathrm{a}}\end{array}$ \\
\hline
\end{tabular}

Means for individual nutrients differ $(P \leq 0.05)$ among grazing treatments within each season when followed by a different letter.

term rest in the exclosure. The percentage of available $\mathrm{N}$ as indicated by ADIN did not vary among treatments.

None of the grazing treatments resulted in an overall advantage in IVDMD (Table 1) and certainly none for wintering elk. The winter ADF values were lower in the regrowth and 1 year rest treatments compared to the exclosure. However, this difference is of questionable biological significance and was not enough to influence the overall IVDMD values which did not differ among treatments during winter. In the same manner, winter NDF was less in the regrowth treatment, but the difference had no statistical influence on winter IVDMD.

Values for all nutrients (Table 1) fell within the expected levels as previously reported by season (Blaisdell et al. 1952, Hamilton and Gilbert 1972, Pitt 1986, Westenskow-Wall et al. 1994). Nitrogen is usually the nutrient of greatest interest for wildlife welfare (Nelson and Leege 1982). It is difficult to provide an exact $\mathrm{N}$ requirement for elk maintenance because the quantity provided will vary with digestion coefficient and intake. Nelson and Leege (1982) estimate the $\mathrm{N}$ content forage requirement for elk maintenance to be about $0.9 \%$. Their estimate is based on a $\mathrm{N}$ digestion coefficient of 0.55 with a consumption rate of $20 \mathrm{~g} / \mathrm{kg}$ of body weight. They conclude that elk would encounter $\mathrm{N}$ deficiency if the $\mathrm{N}$ content of the forage dropped below $0.8 \%$. Using Nelson and Leege's (1982) estimates we approximate elk daily intake rates would need to increase to $36 \mathrm{~g}, 39 \mathrm{~g}$, and $40 \mathrm{~g} / \mathrm{kg}$ of 
body weight in the spring grazed, 1 year of rest, and long-term rest treatments, respectively, to meet the $0.9 \% \mathrm{~N}$ maintenance requirement. These intakes are not likely to occur as elk generally decrease consumption with elevated fiber levels which occur in winter (Table 1) (Geis 1954, Helwig 1957). Further, it is not likely that the digestion coefficient for $\mathrm{N}$ would be as high as 0.55 during the winter at our study site. The IVDMD during winter ranged from $21.1 \%$ to $23.4 \%$ for the 3 treatments. However, the ADIN values in our study are all low, thereby indicating a relatively high amount of the total $\mathrm{N}$ in bluebunch wheatgrass is available during all seasons.

Nelson and Leege (1982) state that on 14 September, estimated to be the first day of gestation for elk, the minimum dietary $\mathrm{N}$ required is $0.82 \%$ for maintenance with any excess being available for weight gain. During the fall and winter at our study site, bluebunch wheatgrass does not meet this minimum $\mathrm{N}$ level. By October the $\mathrm{N}$ levels range from a low of $0.53 \%$ in the long-term rest of the exclosure to a high of $0.74 \%$ in the regrowth from the spring grazing treatment. During winter the range is from $0.46 \%$ to $0.51 \%$ in the same treatments respectively. Apparently bluebunch wheatgrass at our location does not meet gestation requirements for elk during the entire gestation period if near normal consumption of $20 \mathrm{~g} / \mathrm{kg}$ of body weight is maintained.

Nelson and Leege (1982) estimate that the maximum dietary $\mathrm{N}$ requirement for maintenance of $0.9 \%$ is reached on approximately 13 November. Nitrogen in bluebunch wheatgrass is nearly at its low point for the year at that time. The $0.9 \%$ requirement remains throughout winter until spring greenup. Requirements beyond maintenance for pregnancy are not important until approximately 1 February, which is about day 140 of gestation (Nelson and Leege 1982). At that time $\mathrm{N}$ requirements rise about $0.1 \%$ above that required for maintenance. By 1 June, the approximate day of parturition, the minimum dietary $\mathbf{N}$ requirement is $1.1 \%$ for elk (Nelson and Leege 1982). They estimate that elk will be likely consuming forages containing in excess of $3.2 \% \mathrm{~N}$ at that time, but none of our treatments exceeded more than approximately one-half that level during our June sampling period. Nelson and Leege (1982) cstimate that the N requirement during the peak of lactation is about $20 \%$ greater than a cow elk would require for maintenance, with this percentage being even larger on smaller cows. Apparently our site produces adequate $\mathrm{N}$ in bluebunch wheatgrass through June, but lactation requirements would not be met by August.

Unfortunately there are no elk energy requirement standards that could be compared to digestible dry matter to indicate the value of bluebunch wheatgrass for energy in our study. Murie (1951) knew that elk usually lose weight during winter. He reported that elk calves lose approximately $13 \mathrm{~kg}$ and adults average $25 \mathrm{~kg}$ of weight loss during winter. The majority of this weight loss in elk is over a 35-day period. While apparently no one has defined the optimum allowable annual weight loss for elk, a $20 \%$ loss of body weight in mule deer is expected, and a $30 \%$ loss usually results in death (personal communication, R.J. Mackie).

Bryant (1993) found that minimum dietary maintenance requirements for elk will more likely be met through the fall if at least $30-50 \mathrm{~mm}$ of late summer-early fall rain occurs. During the period influencing our study, nearly twice this amount of precipitation was received during August and September in 1991 and 1993. In 1992, the moisture received during August and
September was within this range, but in 1994 the precipitation was slightly less than half this amount. The effect of precipitation is difficult to determine as it is confounded with the rest-rotation scheme as well as the seasonal observations of nutrient content within years. Long-term annual precipitation near our study site averages $320 \mathrm{~mm}$. Precipitation during our study was $380 \mathrm{~mm}$, $288 \mathrm{~mm}, 425 \mathrm{~mm}$, and $311 \mathrm{~mm}$ between 1991 and 1994 .

Apparent deficiencies of bluebunch wheatgrass to meet nutritional requirements of elk, particularly in the winter, may be partially alleviated by elk grazing strategy. As Cook (1972) pointed out, often the stem-leaf ratio is lower in grazed compared to ungrazed portions of grass plants. This lower stem-leaf ratio is associated with a higher forage quality. If elk are grazing to minimize the amount of stem material in their diet, thereby maximizing nutrient intake, it is very likely that plants clipped to simulate grazing could contain significantly different quantities of nutrients from those grazed naturally. Plants sampled for nutrient content in studies like ours may not represent elk diets. However, we did sample only vegetative material to minimize seasonal variation that could result from the presence of culms during some seasons. This should result in a sample at least as high in forage quality as elk may eat.

In southwest Montana the highest elk concentrations on spring range occur where cattle grazing was heaviest the previous summer (Stevens 1965). Subsequent work in the same area by Grover and Thompson (1986) found that while this was true, clk made the greatest use of these sites when they were located near cover and away from visible roads. This supports conclusions by Hayden-Wing (1979), and Morgantini and Hudson (1979) who concluded elk distribution is influenced primarily by human activities and only secondarily by forage characteristics.

While it is possible that cattle grazing the previous spring may have decreased residual forage therehy increasing more desirable current year's growth of bluebunch wheatgrass on our study area, it does not appear that nutritive values were otherwise affected. Although our results are from only 1 location and 1 grazing system, they do not support the contention of Anderson and Scherzinger (1975) that regrowth from spring cattle grazing of bluebunch wheatgrass, in a normal rest-rotation system, influences nutrient content for wildlife consumption the following winter. There also does not appear to be a significant increase in nutrient content from bluebunch wheatgrass that is grazed in the spring by cattle over that which is totally rested for 1 year or that which is never grazed during the growing season. Hopefully our work will be repeated at other locations to clarify the influence of similar grazing treatments on nutrient content under a variety of environmental conditions.

\section{Literature Cited}

Anderson, E.W. and R.J. Scherzinger. 1975. Improving quality of winter forage for elk by cattle grazing. J. Range Manage. 28:120-125.

Anderson, E.W., D.L. Franzen, and J.E. Melland. 1990. Forage quality as influenced by prescribed grazing. p. 56-70. In: K.E. Severson (ed.). Can livestock be used as a tool to enhance wildlife habitat? USDA Forest Serv. Gen. Tech. Rep. RM-194. Fort Collins, Colo.

AOAC. 1980. Official Methods of Analysis (13th Ed.). Association Official Analytical Chemists, Washington, D.C.

Blaisdell, J.P., A.C. Wiese, and C.W. Hodgson. 1952. Variations in chemical composition of bluebunch wheatgrass, arrowleaf balsamroot, and associated range plants. J. Range Manage. 5:346-353. 
Bryant, L.D. 1993. Quality of bluebunch wheatgrass (Agropyron spicatum) as a winter range forage for Rocky Mountain elk (Cervus elaphus nelsoni) in the Blue Mountains of Oregon. Ph.D. Thesis. Oregon State Univ., Corvallis, Ore.

Cook, C.W. 1972. Comparative nutritive values of forbs, grasses and shrubs. p. 303-310. In: Wildland Shrubs-Their Biology and Utilization. USDA, Forest Serv. Gen. Tech. Rep. INT-1. Ogden, Utah.

Dragt, W.J. 1985. Nutritional and developmental responses of three mountain bunchgrasses to summer cattle and winter elk grazing. M.S. Thesis. Montana State Univ., Bozeman, Mont.

Fiske, C.H. and Y. Sabbarow. 1925. Phosphorus determination. J. Biol. Sci. 66:375.

Frisina, M.R. and F.G. Morin. 1991. Grazing private and public land to improve the Fleecer elk winter range. Rangelands 13:291-294.

Greis, A.F. 1954. The food requirements and relative digestibility of a variety of winter diets fed to elk (Cervus canadensis nelsoni) under controlled conditions. M.S. Thesis. Univ. Montana, Missoula, Mont.

Goering, H.K. and P.J. Van Soest. 1970. Forage fiber analyses (apparatus, reagents, procedures, and some applications). Agr. Handb. 379. ARS, USDA, Washington, D.C.

Grover, K.E. and M.J. Thompson. 1986. Factors influencing spring feeding site selection by elk in the Elkhorn Mountains, Montana. J. Wildl. Manage. 50:466-470.

Hamilton, J.W. and C.S. Gilbert. 1972. Composition of Wyoming range plants and soils. Wyo. Agr. Exp. Sta. .Res. J. 55, Laramie, Wyo.

Harris, L.E. 1970. Nutritional Research Techniques for Domestic and Wild Ruminants. Vol. 1. L.E. Harris Pub., Logan, Ut.

Hayden-Wing, L.D. 1979. Distribution of deer, elk, and moose on a winter range in southeastern Idaho. p. 122-131. In: M.S. Boyce and L.D. Hayden-Wing (eds.). North American elk: ecology, behavior, and management. Univ. Wyoming, Laramie, Wyo.

Helwig, L.L. 1957. The value of conifers as a winter feed for elk (Cervus canadensis nelsoni), determined under controlled conditions. M.S. Thesis. Univ. Montana, Missoula, Mont.

Hormay, A.L. 1970. Principles of rest-rotation grazing and multiple use land managcment. U.S. Forest Service Training Text No. 4 (2200), U.S. Government Printing Office, 1970 0-385-056.
Jurgens, M. 1993. Animal Feeding and Nutrition (7th Ed). Kendall/Hunt Publ. Co. Dubuque, Iowa.

Morgantini, L.E. and R.J. Hudson. 1979. Human disturbance and habitat selection in elk. p. 132-39. In: M.S. Boyce and L.D. Hayden-Wing (eds.). North American elk: ecology, behavior, and management. Univ. Wyoming, Laramie, Wyo.

Murie, O.J. 1951. The elk of North America. Stackpole Co. Harrisburg, Penn.

Nelson, J.R. and T.A. Leege. 1982. Nutritional requirements and food habits. p. 323-367. In: J.W. Thomas and D.E. Toweill (eds.). Elk of North America, ecology and management. Stackpole Books, Harrisburg, Penn.

Pitt, M.D. 1986. Assessment of spring defoliation to improve fall forage quality of bluebunch wheatgrass (Agropyron spicatum). J. Range Manage. 39:175-181.

Robertson, J.B. and P.J. Van Soest. 1977. Dietary fiber estimation in concentrate feedstuffs. J. Anim. Sci. 45 Suppl. l:254. (Abstr.).

Severson, K.E. and P.J. Urness. 1994. Livestock grazing: a tool to improve wildlife habitat. p. 232-249. In: M. Vavra, W.A. Laycock, and R. D. Pieper (eds.). Ecological implications of livestock herbivory in the west. Soc. for Range Manage., Denver, Colo. 80206.

Snedecor, G.W. and W.G. Cochran. 1980. Statistical methods. Jowa State Univ. Press, Ames, lowa.

Stevens, D.R. 1965. Range relationships of elk and livestock in the Crow Creek drainage, Elkhom Mountains, Montana. M.S. Thesis, Montana State Univ., Bozeman, Mont.

Uresk, D.W. and J.F. Cline. 1976. Mineral composition of three perennial grasses in a shrub-steppe community in south-central Washington. J. Range Manage. 19:255-256.

Westenskow-Wall, K.J., W.C. Krueger, L.D. Bryant, and D.R. Thomas. 1994. Nutrient quality of bluebunch wheatgrass regrowth on elk winter range in relation to defoliation. J. Range Manage. 47:240-244.

Willms, W., A. McClean, and C. Kalnin. 1980. Nutritive characteristics of grasses on spring range in south central British Columbia in relation to time, habitat and fall grazing. Can. J. Plant Sci. 60:131-137.

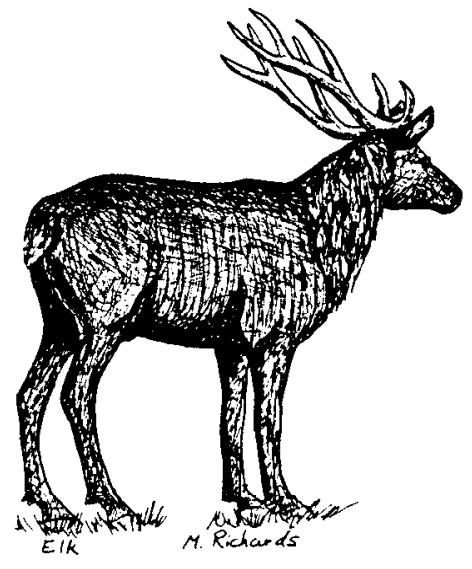

